\title{
The circles of life: age at death estimation in burnt teeth through tooth cementum annulations
}

Inês Oliveira-Santos $1,2, *$

Phone +351912128517

Email ines.olsantos@gmail.com

Márcia Gouveia 3

Eugénia Cunha 1,3

David Gonçalves $1,2,4$ 
Center for Functional Ecology, Laboratory of Forensic Anthropology, Department of Life Sciences, University of Coimbra, 3000- 456 Coimbra, Portugal

${ }^{2}$ Research Centre for Anthropology and Health (CIAS), Department of Life Sciences, University of Coimbra, Calçada Martim de Freitas, 3000456 Coimbra, Portugal $\mathrm{AQ3}$

3 Department of Life Sciences, University of Coimbra, Calçada Martim de Freitas, 3000-456 Coimbra, Portugal

${ }^{4}$ Archaeosciences Laboratory, Directorate General for Cultural Heritage and LARC/CIBIO/InBIO, Rua da Bica do Marquês 2, 1300-087 Lisbon, Portugal

\section{Abstract}

Age at death estimation in burnt human remains is problematic due to the severe heat-induced modifications that may affect the skeleton after a burning event. The objective of this paper was to assess if cementochronology, which focuses on the cementum incremental lines, is a reliable method of age estimation in burnt remains. Besides the classical approach based on the counting of incremental lines, another approach based on the extrapolation of incremental lines taking into account the cement layer thickness and the incremental line thickness was investigated. A comparison of the performance of the two techniques was carried out on a sample of 60 identified monoradicular teeth that were recently extracted at dentist offices and then experimentally burnt at two maximum temperatures (400 and $900{ }^{\circ} \mathrm{C}$ ). Micrographs of cross-sections of the roots were taken via an optical microscope with magnification of $\times 100, \times 200$ and $\times 400$. Incremental line counting and measurements were carried out with the ImageJ software. Age estimation based on incremental line counting in burnt teeth had no significant correlation with chronological age ( $p=0.244$ to 0.914$)$ and led to large absolute mean errors (19 to 21 years). In contrast, age estimation based on the extrapolation approach showed a significant correlation with known age $(p=$ 0.449 to 0.484 ). In addition, the mean absolute error of the latter was much smaller (10 to 14 years). The reason behind this discrepancy is the heat- induced dimensional changes of incremental lines that affect their visibility and individualization thus complicating line counting. Our results indicated that 
incremental lines extrapolation is successful at solving this problem and that the resulting age estimation is much more reliable.

\section{Keywords}

Forensic anthropology

Cementochronology

Heat-induced changes

Incremental lines

Dental age estimation

\section{Introduction}

Burnt human remains are frequently recovered from forensic settings such as mass disasters, accidental fires, homicides, or suicides [ $1-4$ ]. They may be recovered in variable states of preservation and heat-induced changes hence the importance of understanding the consequences of fire exposure to the estimation of the biological profile [ $1-6$ ]. The aim of this paper is to better understand heat-induced alteration of the human dentition as well as to assess the potential of cementochronology for the age at death estimation of unknown individuals based on burnt dental remains. Cementochronology is here defined as the microscopic analyses of the cementum layer involving the counting of tooth cementum incremental lines (IL). When IL is added to the tooth sex-specific age of mineralization, an age estimation can be obtained.

The methodology currently available to estimate the biological profile from burnt human skeletal remains is still deficient, especially for what age at death is concerned due to their usual fragmentation [ $2,7-9$ ]. Thus becomes essential to apply a multifactorial approach in the bioanthropological analysis and dive into more complex but far more accurate methods [ 10 ]. In this regard, teeth are very pertinent study objects since they are one of the most resilient parts of the human skeleton, even after being subjected to burning [ 8,11$]$. Nonetheless, only the dental root provides good prospects for age at death estimation in such cases because it is often protected from heat by alveolar bone and soft tissues [ 8 , $12-14$ ] and even when it is not, it tends to resist rather well [ 15, 16 ]. In addition, dentine and cement changes have a predictable association with chronological age [ $12-14,17$ ]. In fact, several investigations have previously focused on dental features that are demonstrably related to chronological age. That is the case of root translucency, pulp/tooth ratio and racemization of the dentin aspartic acid [ $18-21$ ]. However, they are less useful or even inapplicable whenever teeth are subjected to high temperatures [ 7 ].

In contrast, cementochronology has yielded promising results [ 8, 22-24 ] 
suggesting that this histological technique may be reliably applied to burnt teeth. Specifically, an association of cement apposition and layering with age was first reported by Black (1887, in Schroeder et al. [ 25 ]) and afterwards reaffirmed by Gustafson [ 18 ]. This was further demonstrated in several researches [ 26-28] that resulted in the technique designated as cementochronology or as tooth cementum annulation (TCA). Since its first use in human teeth by Stott et al. [29 ], it has been widely investigated although with contrasting outcomes. While some considered it to be a promising technique [30-32 ], others advised against it or stated that it had limited potential [ 33 - 35 ]. Therefore, no consensus has yet been reached, and this is probably the result of using different samples, dissimilar microscopic settings and of inter-observer variation [ 36,37 ].

The cementochronological analysis of burnt teeth encompasses an additional challenge. They are vulnerable to heat-induced modifications that may limit cementochronological approaches. For example, dimensional changes may cause the shrinkage of incremental lines which in turn leads to their agglomeration [ 8 ]. Such process can prevent the application of incremental line counting (ILC) since many of the lines become indistinguishable from one another and thus impossible to enumerate. To solve this problem, we decided to test an alternative approach consisting on the extrapolation of the amount of incremental lines (ILE). By assessing the thicknesses of the cementum layer and of two welldefined IL, we can theoretically estimate how many of the latter may be accommodated into the former. This approach was inspired by the work of Gupta et al. [ 38 ] who assessed the total number of IL in non-burnt teeth in a similar manner. If proven to work, such extrapolation would have the advantage of bypassing the problem of heat-induced dimensional changes affecting incremental lines.

To assess the validity of the extrapolation approach, a sample of teeth recently extracted from living patients at dentist offices was used. After being experimentally burnt, a comparison between the conventional ILC and the ILE approaches was carried out on the sample of teeth with the aim of determining if any of the procedures could confidently estimate age at death.

\section{Material and methods}

A sample of 717 recently extracted teeth, of known age and sex, from all types and quadrants were collected from Portuguese dental clinics after informed consent (Ref. 108-CE-2014). All teeth were carefully cleansed of remaining soft tissues and bone and then ink marked with an accession number. From the total sample, only 60 teeth (23 upper and 21 lower incisors, as well as 7 upper and 8 lower canines) from 30 females and 22 males with ages from 22 to 88 years old (mean 58 years, sd 14.5 years) were used since the remaining did not meet the 
criteria. Sample selection took into consideration that (1) all donors should be older than 18 years old; (2) teeth were either incisors or canines to facilitate the sectioning process (in situ anterior teeth are also some of the most affected by fire [ 1 ]); (3) teeth had no evidence of metallic fillings; (4) the roots were in good conditions; and (5) information about sex and age of the individual was known. No exclusion from the sample based on pathological conditions was undertaken because that would have dramatically shorten the sample which was composed of teeth that were mostly extracted for that very same reason. Causes for extraction on the analysed sample were described as follows: periodontal disease $(n=25)$, caries $(n=15)$, fractures $(n=6)$, caries and periodontal disease $(n=4)$, mobility $(n=2)$, destruction $(n=2)$, infection $(n=1)$ and pain $(n=1)$. The cause of extraction of four teeth was not disclosed by dentists. Also, to avoid a small sample size, no exclusion based on tooth side was carried out. According to Azaz et al. [ 27 ] and Solheim [ 28 ], laterality has no effect on tooth cementum apposition so the pooling of teeth from both sides was justifiable.

The presence of some heat-induced changes was recorded to assess if they could interfere with the visibility and individualization of cementum incremental lines. Line individualization implies that incremental lines can be distinguished from one another. The colour of teeth was recorded as well as fissures and warping affecting the root. In addition, teeth dimensions were taken with a digital calliper (Mitutoyo Digimatic, accuracy $0.01 \mathrm{~mm}$ ). The standard measurements followed in this experiment included the maximum root height as well as the mesio-distal and bucco-lingual diameters at the mid-height of the root. This latter procedure was undertaken both before and after the experimental burning to assess heatinduced dimensional changes. Teeth were subjected to two controlled burnings in an electric muffle (Barracha K3, three-phased). One sub-sample comprising 30 teeth was exposed to $400{ }^{\circ} \mathrm{C}$ for $2 \mathrm{~h}$ while another 30 teeth were subjected to $900{ }^{\circ} \mathrm{C}$ for $3 \mathrm{~h}$. The temperature was then allowed to naturally decrease down to room temperature. Therefore, temperature increments were of 3.33 and $5.00{ }^{\circ} \mathrm{C} / \mathrm{min}$, respectively. Afterwards, all teeth were embedded in histological resin (Technovit 7200 VLC_Kulzer) and polymerized for $7 \mathrm{~h} \mathrm{(Exakt \circledR} 520$ Light Polymerization Unit) to allow sectioning them without damaging their integrity. Cross sectioning was executed at the middle third of the root with a diamond band saw (Exakt® Band System 300 CL/CP). Two mesio-distal parallel cuts were performed to each tooth root with a 2-mm thickness each (Fig. 1 ). One of the sections was kept as a back-up since teeth were very brittle after the burning process.

\section{Fig. 1}

Teeth burnt at $400{ }^{\circ} \mathrm{C}$ embedded in histological resin, after perpendicular sectioning process, $2 \mathrm{~mm}$ each, in the middle third of the root following Maat et al. 


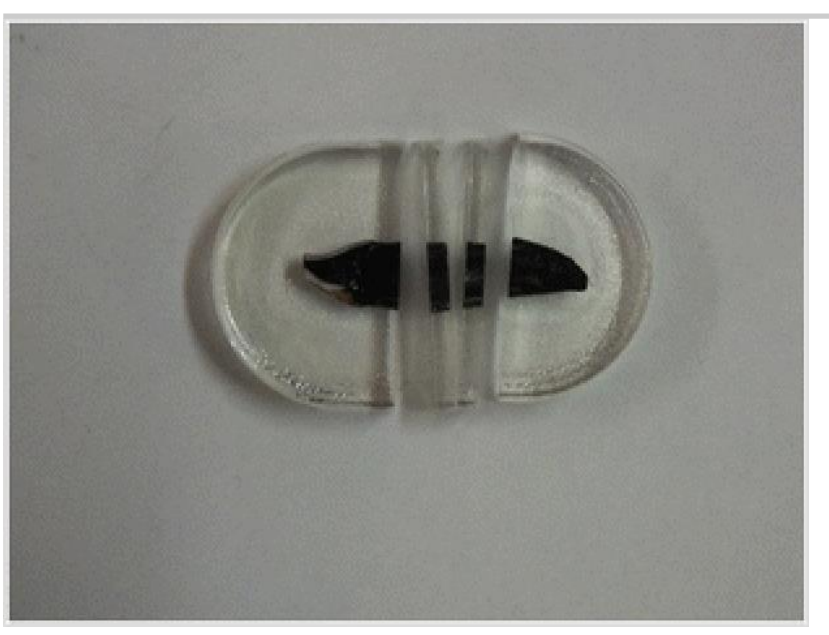

One of the sections was then fixated and polished (Micro Grinding System Exakt® 400 CS) until an approximately 70- $\mu \mathrm{m}$ thickness was achieved. No staining technique was used since it is not essential to distinguish the lines after the section and polishing [ 39 ]. Observations were performed through an optical microscope with magnifications of $\times 100, \times 200$ and $\times 400$ (Nikon Eclipse E600) and micrographs of areas with better visibility were taken with a coupled camera (Nikon DXM 1200C) using the Nikon ACT software. Incremental line counting and measurements of their thickness as well as of cement thickness were performed by using the image processing software Image $(1.48 \mathrm{v})$. An IL is composed of one dark band and one light band, each pair assumed to correspond to 1 year [ $8,29,32$ ]. The ILC was performed on the mesial, distal, buccal and lingual areas to assess eventual divergence in terms of number of lines. For ILE, cement thickness (C) was carefully measured from the dentine/cement border to the external border of cement. Then, the thickness of two contiguous and clearly visible IL (L) was taken. Therefore, this thickness refers to two incremental lines (Fig. 2 ). This procedure was performed three times per slide, and the median value was selected for analysis.

\section{Fig. 2}

Section from a canine tooth of a 37-year-old female, burnt at $900{ }^{\circ} \mathrm{C}$ illustrating the standard measurements required for incremental line extrapolation (ILE). Cement thickness $(C)$ is measured from the dentin/cement border to the external border of cement. Two incremental lines $(L)$ are measured in a clearly visible area. The ILE is obtained with the following formula: $I L E=(\mathrm{L} / 2)^{*} C$. Magnification:

$\times 400$, scale $25 \mu \mathrm{m}$ 


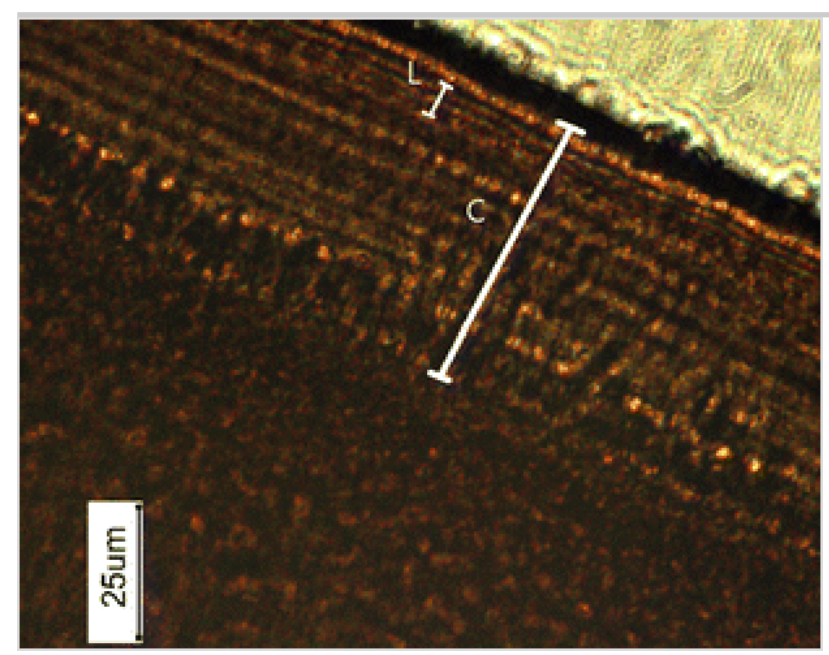

For age estimation, the number of IL obtained both by counting and extrapolation was added to the sex-specific age of mineralization of the analysed teeth. For this purpose, the age references provided by Haavikko [40] were used.

Intra-observer error and inter-observer error for ILC were evaluated on a sample of 20 micrographs by using the relative technical error of measurement (\%TEM) following Perini et al. [ 41 ]. The same procedure was carried out for ILE thickness measurements in five micrographs. Statistical analyses were computed on SPSS (version 20.0) with the purpose of testing the associations between known age and estimated age. Either the Pearson or the Spearman Rho coefficient correlations were used depending on whether or not the parametric assumptions were fulfilled. 


\section{Results}

Heat-induced colour changes were evident in both groups (Fig. 3 ). Teeth subjected to heat treatment up to $400{ }^{\circ} \mathrm{C}$ presented a darker colouration at the root level, ranging from dark-brown to black. At this maximum temperature, the crown still presented its natural colour. On the other hand, teeth burnt at $900{ }^{\circ} \mathrm{C}$ showed lighter colouration. The root became completely white and the crown presented colours ranging from dark to lighter grey. Microscopic analyses allowed us to verify that these colour alterations extended to the dentine. Although not drastically, the darker coloration on the teeth burnt at $400{ }^{\circ} \mathrm{C}$ interfered negatively with the visibility of IL because it decreased light penetration of the sections. Fissures and fractures were observed both at the crown and root levels. However, unlike the crown, the root always remained well preserved at both temperatures. At the microscopic level, micro-fractures were observable both in the dentine and cement, also at both temperatures (Fig. 4 ). At $900{ }^{\circ} \mathrm{C}$, the cement layer had a more fragmented appearance. However, analysed incremental lines were visible enough to allow for cementochronological age estimation in most cases (Fig. 5 ). Only four teeth rendered no results, either because the cement structure was not preserved or due to poor visibility of the lines.

\section{Fig. 3}

Upper right canine, before $(a)$ and after $(a l)$ burning at $400{ }^{\circ} \mathrm{C}$; and lower left canine, before (b) and after burning (b1) at $900{ }^{\circ} \mathrm{C}(1 \mathrm{~cm}$ scale, distal views). Different colour changes are observable at the two maximum temperatures

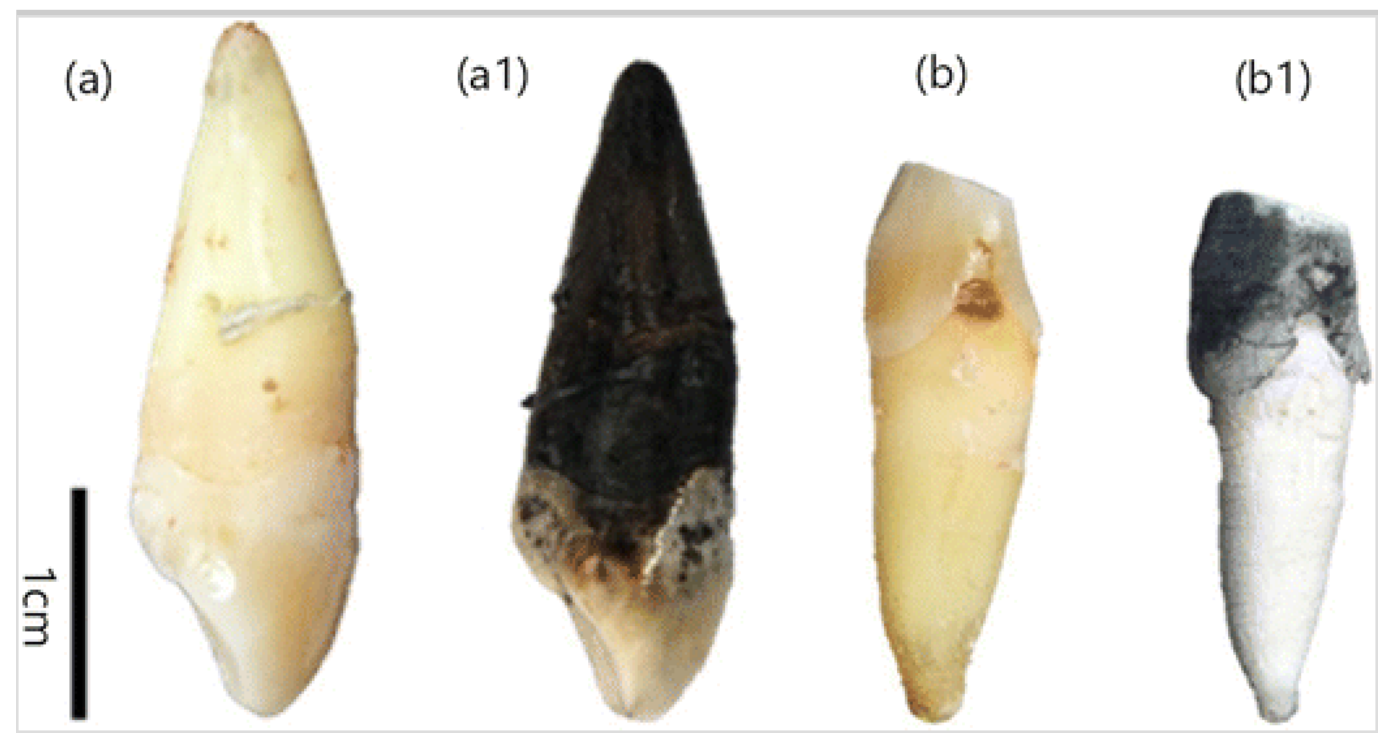

\section{Fig. 4}

Transverse section of the root of a lower incisor (41) burnt at $900{ }^{\circ} \mathrm{C}$ from a 48 - year-old female, displaying fissures in both the dentine and the cement (arrows). Magnification: $\times 20,0.5 \mathrm{~mm}$ scale 


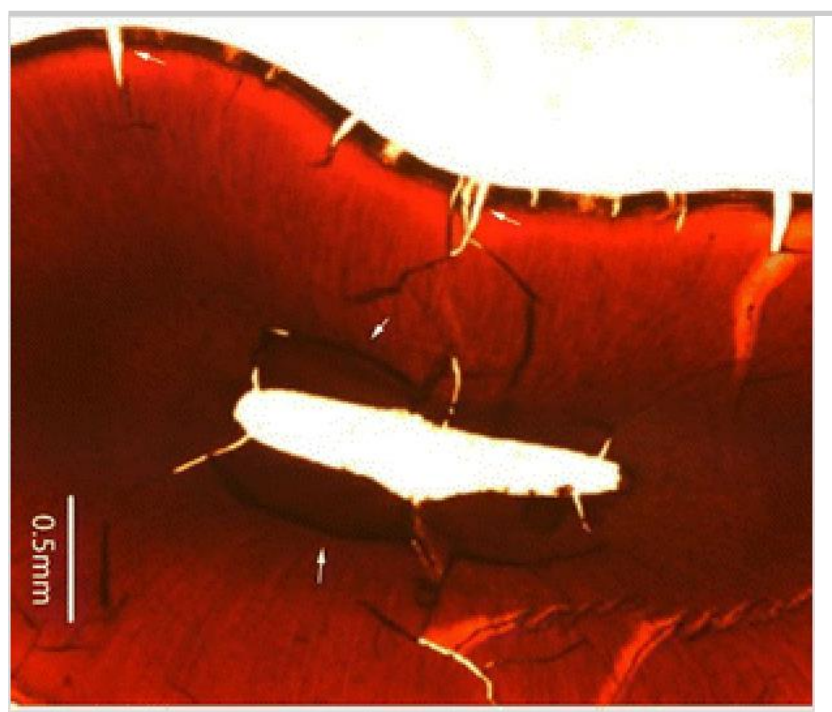

\section{Fig. 5}

Cement layer in transverse section of an upper canine from a 62-year-old female burnt at $400{ }^{\circ} \mathrm{C}$. Magnification: $\times 100,100 \mu \mathrm{m}$ scale

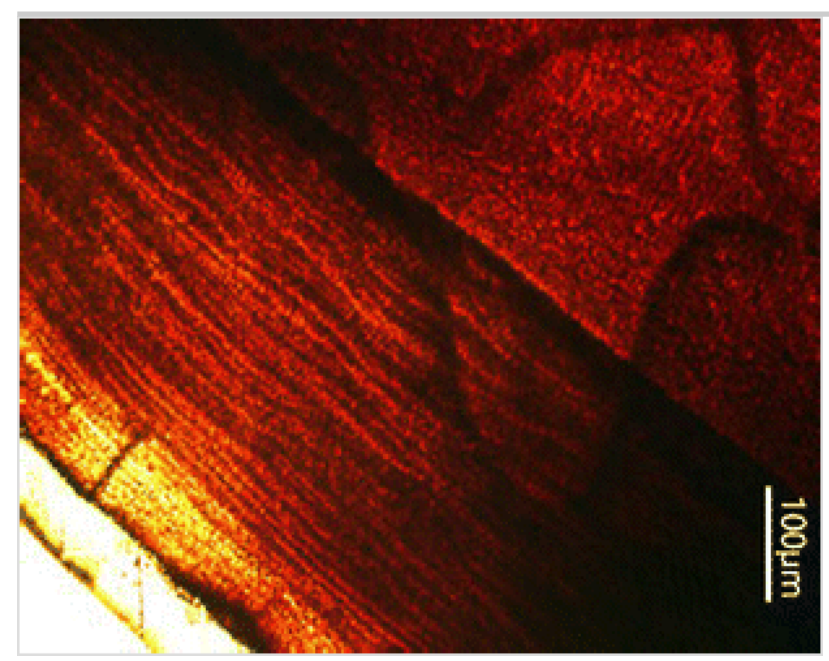

Evident differences on heat-induced dimensional changes were observed between the teeth burnt at different maximum temperatures (Table 1 ). A greater mean relative shrinkage was observed on teeth burnt at $900{ }^{\circ} \mathrm{C}$ than on teeth burnt at $400{ }^{\circ} \mathrm{C}$. It should also be noted that some cases of heat-induced expansion were also documented. These were more frequent on the $400{ }^{\circ} \mathrm{C}$, where 19 teeth showed expansion of at least 1 of the measurements that were assessed-root height, mesio-distal and bucco-lingual diameter. Such event also occurred on eight teeth burnt at $900{ }^{\circ} \mathrm{C}$.

\section{Table 1}

Heat-induced dimensional changes of root height, mesio-distal diameter (MD) and buccolingual diameter (BL) in the teeth burnt at 400 and $900{ }^{\circ} \mathrm{C}$

\begin{tabular}{|l|l|}
\hline $400{ }^{\circ} \mathrm{C}$ & $900{ }^{\circ} \mathrm{C}$
\end{tabular}




\begin{tabular}{|c|c|c|c|c|c|c|c|c|}
\hline \multirow{2}{*}{$\begin{array}{c}\text { vimensionaı } \\
\text { changes }\end{array}$} & & & & & & & & \\
\hline & $\%$ & $\sigma$ & Min & Max & $\%$ & $\boldsymbol{\sigma}$ & Min & $\operatorname{Max}$ \\
\hline Root height & -3.40 & 8.26 & -29.47 & 10.77 & -14.90 & 9.68 & -35.97 & 5.66 \\
\hline MD diameter & -4.01 & 10.30 & -29.35 & 9.96 & -7.71 & 7.71 & -32.2 & 49.35 \\
\hline BL diameter & -2.59 & 5.65 & -15.57 & 8.44 & -13.55 & 10.42 & -46.15 & 7.76 \\
\hline
\end{tabular}

The ILC relative technical error of measurement (\%TEM) for the intraobservations was small (3.1\%) with a reliability coefficient (RC) of $95 \%$. Interobserver error was slightly larger $(5.7 \%)$ with a RC of $84.0 \%$. An intraobserver \% TEM of $4.0 \%$ was calculated for the incremental lines thickness measurement procedure with a RC of $90.0 \%$. An inter-observer \% TEM of 5.6\% with a RC of $80.0 \%$ was observed. The measurement of the cementum thickness produced an intra-observer \% TEM of $5.8 \%$ with a RC of $90.0 \%$. As for the inter-observer error, it produced a \% TEM of $8.7 \%$ with a RC of $90.0 \%$.

Results for age estimation based on both ILC and ILE approaches appear on Tables 2 and 3 for the former and Tables 4 and 5 for the latter. Descriptive statistics are presented on Table 6 . The mean age estimation obtained through the ILE extrapolation technique was much closer to the actual mean chronological age in both samples. No statistically significant correlation was found between ILC age estimation and chronological age at both $400{ }^{\circ} \mathrm{C}(r=0.022, p=0.914)$ and $900{ }^{\circ} \mathrm{C}$ $(r=0.228, p=0.244)$. Also, the number of IL assessed through ILC in each section - mesial, distal, buccal and lingual - was very discrepant. It ranged from 11 to 45 lines at $400{ }^{\circ} \mathrm{C}$ and from 11 to 55 lines at $900{ }^{\circ} \mathrm{C}$. The average number of lines counted in each section is presented in Table 7 . A statistically significant correlation was found between ILE age estimation and chronological age at 400 ${ }^{\circ} \mathrm{C}(r=0.484, p=0.036)$ and $900{ }^{\circ} \mathrm{C}(r$ $=0.449, p=0.031)$. Such contrast between the two techniques is well demonstrated by the age estimation mean absolute error associated with them both. The ILC resulted in mean absolute errors of 19.4 years in teeth burnt at 400 ${ }^{\circ} \mathrm{C}$ and 21.6 years in teeth burnt at $900{ }^{\circ} \mathrm{C}$. The ILE approach presented smaller mean absolute errors of 10.8 years for teeth burnt at $400{ }^{\circ} \mathrm{C}$ and 14.0 years for teeth burnt at $900{ }^{\circ} \mathrm{C}$. Therefore, the mean absolute error was cut by half after applying the ILE technique.

\section{Table 2}

Age estimation through counting of incremental lines in teeth burnt at $400{ }^{\circ} \mathrm{C}$ 
Age estimate

\begin{tabular}{|c|c|c|c|c|c|}
\hline Teeth & CA (years) & NL & MA (years) & Min (years) & Max (years) \\
\hline 32 & 48 & 25 & $9.0 \pm 1.3$ & 32.7 & 35.3 \\
\hline 12 & 56 & 31 & $10.8 \pm 1.9$ & 39.9 & 43.7 \\
\hline 13 & 43 & 33 & $13.6 \pm 3.7$ & 42.9 & 50.3 \\
\hline 12 & 43 & 18 & $10.8 \pm 1.9$ & 26.9 & 30.7 \\
\hline 21 & 43 & 14 & $9.8 \pm 2.6$ & 21.2 & 26.4 \\
\hline 31 & 53 & 32 & $8.0 \pm 2.1$ & 37.9 & 42.1 \\
\hline 23 & 22 & 34 & $12.7 \pm 3.2$ & 43.5 & 49.9 \\
\hline 23 & 53 & 30 & $12.7 \pm 3.2$ & 39.5 & 45.9 \\
\hline 12 & 57 & 14 & $10.8 \pm 1.9$ & 22.9 & 26.7 \\
\hline 22 & 57 & 25 & $10.8 \pm 1.9$ & 33.9 & 37.7 \\
\hline 32 & 59 & 28 & $9.0 \pm 1.3$ & 35.7 & 38.3 \\
\hline 12 & 60 & 19 & $9.6 \pm 0.9$ & 27.7 & 29.5 \\
\hline 23 & 62 & 31 & $12.7 \pm 3.2$ & 40.5 & 46.9 \\
\hline 43 & 49 & 32 & $11.5 \pm 2.5$ & 41.0 & 46.0 \\
\hline 42 & 49 & 12 & $9.0 \pm 1.3$ & 19.7 & 22.3 \\
\hline 11 & 77 & - & $9.8 \pm 2.6$ & - & - \\
\hline 21 & 77 & 18 & $9.3 \pm 0.9$ & 26.4 & 28.2 \\
\hline 31 & 61 & 17 & $8.0 \pm 2.1$ & 22.9 & 27.1 \\
\hline 41 & 48 & 15 & $8.0 \pm 2.7$ & 20.3 & 25.7 \\
\hline 42 & 61 & 18 & $9.6 \pm 2.1$ & 25.5 & 29.7 \\
\hline 41 & 40 & 34 & $8.0 \pm 2.1$ & 39.9 & 44.1 \\
\hline 42 & 40 & 23 & $9.0 \pm 1.3$ & 30.7 & 33.3 \\
\hline 23 & 47 & 18 & $12.7 \pm 3.2$ & 27.5 & 33.9 \\
\hline 31 & 33 & 16 & $8.0 \pm 2.7$ & 21.3 & 26.7 \\
\hline 32 & 33 & 32 & $9.6 \pm 2.1$ & 39.5 & 43.7 \\
\hline 33 & 33 & - & $13.2 \pm 1.9$ & - & - \\
\hline 21 & 66 & 32 & $9.8 \pm 2.6$ & 39.2 & 44.4 \\
\hline 11 & 73 & 45 & $9.8 \pm 2.6$ & 52.2 & 57.4 \\
\hline 33 & 61 & 27 & $11.5 \pm 2.5$ & 36.0 & 41.0 \\
\hline 21 & 69 & - & $9.3 \pm 0.9$ & - & - \\
\hline
\end{tabular}


$C A$ chronological age, $N L$ number of lines, $M A$ mineralization age (root complete), Min minimum age estimated, Max maximum age estimated; age in years (years)

\section{Table 3}

Age estimation through counting of incremental lines in teeth burnt at $900{ }^{\circ} \mathrm{C}$

\begin{tabular}{|c|c|c|c|c|c|}
\hline \multicolumn{6}{|c|}{ Age estimate } \\
\hline Teeth & CA (years) & Ln & MA (years) & Min (years) & Max (years) \\
\hline 22 & 61 & 29 & $9.6 \pm 0.9$ & 37.7 & 39.5 \\
\hline 42 & 77 & 19 & $9.0 \pm 1.3$ & 26.7 & 29.3 \\
\hline 21 & 76 & 36 & $9.3 \pm 0,9$ & 44.4 & 46.2 \\
\hline 22 & 39 & 24 & $10.8 \pm 1.9$ & 32.9 & 36.7 \\
\hline 33 & 52 & 37 & $11.5 \pm 2.5$ & 46.0 & 51.0 \\
\hline 33 & 73 & 39 & $11.5 \pm 2.5$ & 48.0 & 53.0 \\
\hline 41 & 48 & 31 & $8.0 \pm 2.1$ & 36.9 & 41.1 \\
\hline 43 & 78 & 45 & $13.2 \pm 1.9$ & 53.3 & 60.1 \\
\hline 21 & 61 & 39 & $9.8 \pm 2.6$ & 46.2 & 51.4 \\
\hline 11 & 55 & 21 & $9.8 \pm 2.6$ & 28.2 & 33.4 \\
\hline 43 & 61 & 42 & $13.2 \pm 1.9$ & 53.3 & 57.1 \\
\hline 12 & 57 & 37 & $10.8 \pm 1.9$ & 45.9 & 49.7 \\
\hline 13 & 57 & 24 & $13.6 \pm 3.7$ & 33.9 & 41.3 \\
\hline 12 & 65 & 33 & $10.8 \pm 1.9$ & 41.9 & 45.7 \\
\hline 32 & 62 & 55 & $9.0 \pm 1.3$ & 62.7 & 65.3 \\
\hline 11 & 82 & 21 & $9.3 \pm 0.9$ & 29.4 & 31.2 \\
\hline 13 & 61 & 49 & $13.6 \pm 3.7$ & 58.9 & 66.3 \\
\hline 23 & 43 & - & $13.6 \pm 3.7$ & - & - \\
\hline 31 & 88 & 38 & $8.0 \pm 2.1$ & 43.9 & 48.1 \\
\hline 33 & 37 & 23 & $11.5 \pm 2.5$ & 32.0 & 37.0 \\
\hline 42 & 88 & 53 & $9.0 \pm 1.3$ & 60.7 & 63.3 \\
\hline 12 & 54 & - & $9.6 \pm 0.9$ & - & - \\
\hline 23 & 64 & 23 & $12.7 \pm 3.2$ & 32.5 & 38.9 \\
\hline 32 & 73 & 33 & $9.0 \pm 1.3$ & 40.7 & 43.3 \\
\hline
\end{tabular}




\begin{tabular}{|l|l|l|l|l|l|}
\hline 12 & 66 & 25 & $10.8 \pm 1.9$ & 33.9 & 37.7 \\
\hline 41 & 75 & 21 & $8.0 \pm 2.0$ & 26.9 & 31.1 \\
\hline 21 & 67 & 26 & $9.3 \pm 0.9$ & 34.4 & 36.2 \\
\hline 31 & 62 & 31 & $8.0 \pm 2.7$ & 36.3 & 41.7 \\
\hline 42 & 78 & 43 & $9.6 \pm 2.1$ & 50.5 & 54.7 \\
\hline 42 & 48 & 28 & $9.0 \pm 1.3$ & 35.7 & 38.3 \\
\hline
\end{tabular}

$C A$ chronological age, $N L$ number of lines, $M A$ mineralization age (root complete), Min minimum age estimated, Max maximum age estimated; age in years (years)

\section{Table 4}

Age estimation through extrapolation of the number of incremental lines in teeth burnt at $400{ }^{\circ} \mathrm{C}$

\section{Estimate}

\begin{tabular}{|c|c|c|c|c|c|c|c|}
\hline Teeth & $\underset{\text { (years) }}{\text { CA }}$ & $\underset{(\mathbf{m m})}{\mathbf{L}}$ & $\underset{(\mathbf{m m})}{\mathbf{C}}$ & NL & $\begin{array}{c}\text { MA } \\
\text { (years) }\end{array}$ & $\underset{\text { (years) }}{\operatorname{Min}}$ & $\underset{\text { (years) }}{\text { Max }}$ \\
\hline 32 & 48 & 0.0034 & 0.0719 & 42.3 & $9.0 \pm 1.3$ & 50.0 & 52.6 \\
\hline 12 & 56 & 0.003 & 0.1081 & 72.1 & $10.8 \pm 1.9$ & 81.0 & 84.8 \\
\hline 13 & 43 & 0.0048 & 0.084 & 35.0 & $13.6 \pm 3.7$ & 44.9 & 53.3 \\
\hline 12 & 43 & 0.0028 & 0.0448 & 32.0 & $10.8 \pm 1.9$ & 40.9 & 44.7 \\
\hline 31 & 53 & 0.0026 & 0.0432 & 33.2 & $8.0 \pm 2.1$ & 39.1 & 43.3 \\
\hline 12 & 57 & 0.0037 & 0.0607 & 32.8 & $10.8 \pm 1.9$ & 41.7 & 45.5 \\
\hline 12 & 60 & 0.0025 & 0.0531 & 42.5 & $9.6 \pm 0.9$ & 51.2 & 53.0 \\
\hline 43 & 49 & 0.0021 & 0.0273 & 26.0 & $11.5 \pm 2.5$ & 35.0 & 40.0 \\
\hline 42 & 49 & 0.0032 & 0.1028 & 64.3 & $9.0 \pm 1.3$ & 72.0 & 74.6 \\
\hline 41 & 48 & 0.0031 & 0.0647 & 41.7 & $8.0 \pm 2.7$ & 47.0 & 52.4 \\
\hline 42 & 61 & 0.0039 & 0.0754 & 38.7 & $9.6 \pm 2.1$ & 46.2 & 50.4 \\
\hline 41 & 40 & 0.0033 & 0.0861 & 52.2 & $8.0 \pm 2.1$ & 58.1 & 62.3 \\
\hline 42 & 40 & 0.0026 & 0.0739 & 56.8 & $9.0 \pm 1.3$ & 64.5 & 67.1 \\
\hline 23 & 47 & 0.0028 & 0.0523 & 37.4 & $12.7 \pm 3.2$ & 46.9 & 53.3 \\
\hline 31 & 33 & 0.0035 & 0.0478 & 27.3 & $8.0 \pm 2.7$ & 32.6 & 38.0 \\
\hline 21 & 66 & 0.0056 & 0.1248 & 44.6 & $9.8 \pm 2.6$ & 51.8 & 57.0 \\
\hline 11 & 73 & 0.0035 & 0.1271 & 72.6 & $9.8 \pm 2.6$ & 79.8 & 85.0 \\
\hline 33 & 61 & 0.0028 & 0.0795 & 56.8 & $11.5 \pm 2.5$ & 65.8 & 70.8 \\
\hline
\end{tabular}


$C A$ chronological age, $L$ incremental line thickness (in millimetres), $C$ cementum layer thickness (in millimetres), $N L$ number of lines, $M A$ mineralization age (root complete), Min minimum age estimated, Max maximum age estimated; age in years (years)

\section{AQ4}

\section{Table 5}

Age estimation through extrapolation of the number of incremental lines in teeth burnt at $900{ }^{\circ} \mathrm{C}$

\begin{tabular}{|c|c|c|c|c|c|c|c|}
\hline \multicolumn{8}{|c|}{ Estimate } \\
\hline Teeth & $\begin{array}{c}\text { CA } \\
\text { (years) }\end{array}$ & $\begin{array}{c}\mathrm{L} \\
(\mathbf{m m})\end{array}$ & $\begin{array}{c}\mathrm{C} \\
(\mathrm{mm})\end{array}$ & Ln & $\begin{array}{c}\text { MA } \\
\text { (years) }\end{array}$ & $\begin{array}{c}\text { Min } \\
\text { (years) }\end{array}$ & $\begin{array}{c}\text { Max } \\
\text { (years) }\end{array}$ \\
\hline 22 & 61 & 0.0027 & 0.096 & 70.8 & $9.6 \pm 0.9$ & 79.5 & 81.3 \\
\hline 21 & 76 & 0.0028 & 0.118 & 84.3 & $9.3 \pm 0.9$ & 92.7 & 94.5 \\
\hline 22 & 39 & 0.0028 & 0.068 & 48.5 & $10.8 \pm 1.8$ & 57.4 & 61.2 \\
\hline 33 & 52 & 0.0027 & 0.108 & 80.1 & $11.5 \pm 2.5$ & 89.1 & 94.1 \\
\hline 41 & 48 & 0.0035 & 0.064 & 36.3 & $8.0 \pm 2.1$ & 42.2 & 46.4 \\
\hline 43 & 78 & 0.0036 & 0.12 & 66.8 & $13.2 \pm 1.9$ & 78.1 & 81.9 \\
\hline 21 & 61 & 0.002 & 0.079 & 79.0 & $9.8 \pm 2.6$ & 86.2 & 91.4 \\
\hline 11 & 55 & 0.0028 & 0.09 & 64.2 & $9.8 \pm 2.6$ & 71.4 & 76.6 \\
\hline 43 & 61 & 0.0054 & 0.141 & 52.1 & $13.2 \pm 1.9$ & 63.4 & 67.2 \\
\hline 12 & 57 & 0.0035 & 0.092 & 52.4 & $10.8 \pm 1.9$ & 61.3 & 65.1 \\
\hline 13 & 57 & 0.0039 & 0.105 & 53.9 & $13.6 \pm 3.7$ & 63.8 & 71.2 \\
\hline 12 & 65 & 0.0044 & 0.121 & 55.0 & $10.8 \pm 1.9$ & 63.9 & 67.7 \\
\hline 32 & 62 & 0.0041 & 0.162 & 78.9 & $9.0 \pm 1.3$ & 86.6 & 89.2 \\
\hline 13 & 61 & 0.0038 & 0.15 & 78.8 & $13.6 \pm 3.7$ & 88.7 & 96.1 \\
\hline 23 & 43 & 0.0027 & 0.079 & 58.7 & $13.6 \pm 3.7$ & 68.6 & 76.0 \\
\hline 33 & 37 & 0.003 & 0.055 & 36.9 & $11.5 \pm 2.5$ & 45.9 & 50.0 \\
\hline 42 & 88 & 0.0048 & 0.176 & 73.5 & $9.0 \pm 1.3$ & 81.2 & 83.8 \\
\hline 23 & 64 & 0.0037 & 0.089 & 48.1 & $12.7 \pm 3.2$ & 57.6 & 64.0 \\
\hline 12 & 66 & 0.0028 & 0.101 & 72.1 & $10.8 \pm 1.9$ & 81.0 & 84.8 \\
\hline 21 & 67 & 0.0034 & 0.097 & 56.9 & $9.3 \pm 0.9$ & 65.3 & 67.1 \\
\hline 32 & 73 & 0.0047 & 0.111 & 47.2 & $9.0 \pm 1.3$ & 54.9 & 57.5 \\
\hline
\end{tabular}




\begin{tabular}{|l|l|l|l|l|l|l|l|}
\hline 31 & 62 & 0.0037 & 0.114 & 61.4 & $8.0 \pm 2.7$ & 66.7 & 72.1 \\
\hline 42 & 78 & 0.0054 & 0.192 & 71.2 & $9.6 \pm 2.1$ & 78.7 & 82.9 \\
\hline
\end{tabular}

$C A$ chronological age, $L$ incremental line thickness (in millimetres), $C$ cementum layer thickness (in millimetres), $N L$ number of lines, $M A$ mineralization age (root complete), Min minimum age estimated, Max maximum age estimated; age in years (years)

\section{Table 6}

Descriptive statistics for the chronological age and estimated age of individuals based on the incremental lines counting (ILC) and incremental lines extrapolation (ILE) at 400 and $900{ }^{\circ} \mathrm{C}$

\begin{tabular}{|l|l|l|l|l|}
\hline & \multicolumn{2}{|c|}{ ILC } & \multicolumn{2}{c|}{ ILE } \\
\hline Maximum temperature & $400^{\circ} \mathrm{C}$ & $900^{\circ} \mathrm{C}$ & $400^{\circ} \mathrm{C}$ & $900^{\circ} \mathrm{C}$ \\
\hline$n$ & 27 & 28 & 18 & 23 \\
\hline Chronological age mean & 52.4 & 63.6 & 52.4 & 63.6 \\
\hline Chronological age SD & 13.5 & 13.5 & 13.5 & 13.5 \\
\hline Estimated age mean & 34.2 & 40.5 & 51.3 & 63.7 \\
\hline Estimated age SD & 8.5 & 10.6 & 13.6 & 12.3 \\
\hline
\end{tabular}

\section{Table 7}

Average number of IL counted (n) in each section — mesial, distal, buccal, lingual—at 400 and $900{ }^{\circ} \mathrm{C}$. The sections with low visibility were not taken into account

\begin{tabular}{|c|c|c|}
\hline \multirow{2}{*}{ Section } & \multicolumn{2}{|c|}{$n$} \\
\hline & $400{ }^{\circ} \mathrm{C}$ & $900{ }^{\circ} \mathrm{C}$ \\
\hline Mesial & 23 & 32 \\
\hline Distal & 21 & 27 \\
\hline Buccal & 19 & 26 \\
\hline Lingual & 18 & 20 \\
\hline
\end{tabular}

\section{Discussion}

Our results indicated that the root is a valuable source of information to estimate age in burnt teeth. Although its integrity suffered some important alterations, it was usually sufficiently maintained to allow the application of cementochronological procedures. Usually, the ILC approach can beapplied to 
skeletal remains, as previously demonstrated by Großkopf et al. [ 22, 23 ] and Czermak et al. [ 24 ] in archaeological burnt teeth and by Gotcha and Schutkowski [ 8 ] in recently extracted teeth that were burnt under controlled conditions. However, it may only allow experts to estimate a minimum age for the individual [ 24 ]. In our experiment, age obtained through ILC was also underestimated in the majority of cases which had already been observed in both unburnt teeth [ 42 ] and archaeological cremated teeth [24 ]. This contrasted with the results of the ILE approach which allowed us to obtain age estimates significantly correlated with chronological age and benefiting from smaller errors. Such results suggest that a combination of the approaches could therefore result in more informative age estimates.

Our first concern regarding the application of cementochronology to burnt teeth regarded heat-induced changes and to what degree they can interfere with visibility and individualization of cementum incremental lines. Heat-induced colour changes in our sample replicated in part what had been previously reported for teeth [ $12,43-45$ ]. Colour variation according to temperature probably occurred because teeth start losing their organic components, except carbon, around 400 and $600{ }^{\circ} \mathrm{C}$ [ 46 ] and acquire a white colour at higher temperatures when all of it has completely disappeared and the teeth becomes calcined. Although our research verified the presence of cement layers in burnt teeth, it became clear that their visibility and individualization was not equally maintained at both maximum temperatures. Dental tissues become more increasingly translucent with temperature increase [ 14 ]. Therefore, the IL observation was easier on teeth burnt at $900{ }^{\circ} \mathrm{C}$, and a greater average number of lines counted in each section was observed than in the teeth burnt at $400{ }^{\circ} \mathrm{C}$.

The impact of heat-induced warping on IL was more difficult to assess. Apparently, teeth subjected to heat effectively maintained their original shape which contrasts with what happens with bone [ 47,48 ]. Such finding has been previously reported by Sandholzer et al. [ 45 ]. Possibly, this is due to the isotropic distribution of collagen matrices in teeth [ 45 ] which is therefore quite different than the anisotropic organization present in bone [49 ]. Although slight and imperceptible shape changes may have occurred, they did not seem to substantially affect incremental lines visibility. They may have contributed to their agglomeration and thus hamper line counting, but we were unable to demonstrate such association.

Although fissures and fractures were observed at both temperatures thus replicating the findings of other authors [ 45,50 ], the roots in our sample always remained intact. This may have been the result of the slow temperature increment used in this study which aimed for the better preservation of teeth. 
Nonetheless, as was previously stated by Fereira et al. [ 15 ], heat-induced changes may compromise microscopic analyses.

Apparently, heat-induced dimensional changes had a major role on the visibility and individualization of incremental lines. Our results matched the ones obtained by Gocha and Schutkowski [ 8 ] and Gouveia [ 16 ] who found a greater variation of dimensional changes in teeth burnt at higher temperatures. These expansion or shrinkage episodes apparently transformed the structure of cement layers by making incremental lines collapse into each other and turning them indiscernible from one another. This fact, along with the negative effect of other heat-induced changes and the difficulty to achieve thinner sections due to the brittleness of the teeth [ 8,16 ], greatly complicated the application of the ILC approach. This partly explains the poor results that it enabled. The test done on our sample indicated that the ILE approach allowed us to circumvent this problem and to obtain age estimates that were closer to the actual chronological ages in a case by case basis.

The debate about the potential of cementochronology in unburnt teeth has been fuelled by contrasting results [ $30-34$ ]. That trend seems to extend itself to burnt teeth as well. Our results partly diverges from what was previously reported by Gocha and Schutkowski [ 8 ] who advocated that it is possible to estimate age based on ILC in teeth burnt up to $600{ }^{\circ} \mathrm{C}$. Like ourselves, they reported that the order of the fibres composing the incremental lines was corrupted which can be related to strong dimensional changes affecting the medial area of the root [8]. However, we were not as successful in overcoming such problem, and this could be related to possible differences between both works regarding sample composition and preparation or data analysis.

A thoughtful hypothesis would be to directly correlate the cement thickness with the chronological age; however, with heat treatment, the layer undergoes considerable alterations to its expected shape [ 8 ]. This is why IL are such a necessary and valuable guide throughout the analysis and cannot be overlooked.

Our sample was mainly composed of teeth presenting pathologies. The cementogenesis process encompasses periodontal ligament calcification so it is expectable that any disease or mechanical stress affecting this structure will impact cement apposition [ 51 ]. That is the case of hypercementosis and caries. The former visibly modifies the cement layer [ 31,52 ] while the latter can have an impact on the way that biomechanical forces affect teeth and subsequent cement layering [ 31,53 ]. As with periodontal disease, its effect is yet unclear. Some authors claim that it has little or even no impact on the cement apposition [54] while others argue that it has a nefarious impact [ 55 ]. 
Due to this particular nature of our sample, it is important to question if the cement apposition ceased long before extraction date. Seeing we cannot correctly evaluate the degree the pathologies affected the teeth, this variable was not assessed, and we cannot discard it of having influence on our results.

Despite the strong presence of pathologies in our sample, the ILE approach provided promising results. Nonetheless, we saw indications that it may interfere with results. For example, in the case of a lower lateral incisor of a 59-year-old female suffering from periodontal disease, the ILC age estimation was of $37 \pm$ 1.3 years. On the other hand, the ILE age estimation was $122.1 \pm 1.3$ years. The latter was due to an abnormally large cement thickness which led to an unusually large number of extrapolated lines. However, this tooth did not present remarkable dimensional changes after heat treatment $-1.99 \%$ of height shrinkage, $0.78 \%$ of expansion of the bucco-lingual diameter and no alteration in the mesio-distal diameter. Consequently, the impact of such pathologies on the ILE technique cannot be overlooked, and it is important to also test this approach on a pathology-free sample to see if results improve.

The effect of pathologies and mechanical stress on cement apposition and ultimately on cementochronology is difficult to estimate and to overcome. However, our results indicated that overcoming the effect of heat-induced changes on the visibility and individualization of incremental lines may not be as challenging. By following the inspiring work of Gupta et al. [ 38 ], we successfully attempted to extrapolate the number of incremental lines present in the cement layer of burnt teeth. Additionally to a statistically significant correlation between chronological and estimated age, we obtained a much smaller mean absolute error than by using the ILC approach. These promising results require further validation, ideally on larger samples composed of teeth that are free of pathologies. Also, the application of the ILE approach seems to be considerably dependent on experience since the inter-observer \% TEM was close to $10 \%$, although it should be taken into account that one of the observers was completely new to this procedure. Selecting two incremental lines for thickness measurement is more challenging than merely counting lines.

Therefore, additional research is also needed to further enlighten the role of experience in the replicability of the ILE approach.

\section{Conclusion}

This investigation was successful in demonstrating the potential of incremental lines extrapolation for age estimation. The impact of our results on the analysis of burnt skeletal remains is major since it proposes a new and promising methodological approach to estimate age-at-death based on the dentition, which 
is one of the most resilient structures of the human body. By combining ILC and ILE, a minimum age-at-death and an age-at-death estimation interval can be estimated more confidently. In uncontrolled laboratorial settings, dental roots are usually protected by gingivae, periodontal ligaments and alveoli [ 11 ]. Therefore, our research did not entirely replicate the conditions that are so frequently found in actual cases [ 56 ]. However, the protection provided by both hard and soft tissues does not completely insulate teeth from heat. In addition, such insulation works only temporarily in many cases until burning leads to the pyrolysis of soft tissues or to the brittleness and subsequent fragmentation of alveolar bone.

Temperature is the key factor regarding heat-induced changes and some of these (colour; dimensions; fractures) will inevitably take place regardless of the burning sources and of the conditions of the remains. Our investigation focused on a very large range of temperatures that affect skeletal remains from both archaeological and forensic settings. Therefore, the application of cementochronology to real cases seems promising.

\section{Acknowledgments}

The authors would like to thank all the donor and dentists who collaborated in this research. A special thanks goes to Cláudia Brites and the Hard Tissues Laboratory of the Dentistry Department of the Faculty of Medicine of the University of Coimbra. Also, to Maria Teresa Ferreira, for taking her time in revising the text and to Benoit Bertrand for giving valuable advice for this research. David Gonçalves is funded through a postdoctoral research grants (SFRH/BPD/84268/2012) from the Portuguese Foundation for Science and Technology.

\section{References}

1. Fairgrieve SI (2008) Forensic cremation recovery and analysis. CRC Press, USA

2. Ubelaker DH (2009) The forensic evaluation of burned skeletal remains: a synthesis. Forensic Sci Int 183(1):1-5

3. Harbeck M, Schleuder R, Schneider J, Wiechmann I, Schmahl WW, Grupe G (2011) Research potential and limitations of trace analyses of cremated remains. Forensic Sci Int 204(1):191-200

4. Alunni V, Grevin G, Buchet L, Quatrehomme G (2014) Forensic aspect of cremations on wooden pyre. Forensic Sci Int 241:167-172 
5. Thompson TJU (2004) Recent advances in the study of burned bone and their implications for forensic anthropology. Forensic Sci Int 146:S203-S205

6. Gonçalves D (2011) The reliability of osteometric techniques for the sex determination of burned human skeletal remains. Homo 62(5):351-358

7. Cunha E, Baccino E, Martrille L, Ramsthaler F, Prieto J, Schuliar Y, Lynnerup N, Cattaneo C (2009) The problem of aging human remains and living individuals: a review. Forensic Sci Int 193(1):1-13

8. Gocha TP, Schutkowski H (2013) Tooth cementum annulation for estimation of age-at-death in thermally altered remains. J Forensic Sci 58(s1):S151-S155

9. Absolonova K, Veleminsky P, Dobisikova M, Beran M, Zocova J (2013) Histological estimation of age at death from the compact bone of burned and unburned human ribs. J Forensic Sci 58(s1):S135-S145

10. Rösing FW, Graw M, Marré B, Ritz-Timme S, Rothschild MA, Rötzscher K, Schmeling A, Schröder I, Geserick G (2007) Recommendations for the forensic diagnosis of sex and age from skeletons. Homo 58(1):75-89

11. Schmidt CW (2008) The recovery and study of burned human teeth. In: Schmidt CW, Symes SA (eds) The analysis of burned human remains. Academic, London, pp 55-74

12. Merlati G, Danesino P, Savio C, Fassina G, Osculati A, Menghini P (2002) Observations on dental prostheses and restorations subjected to high temperatures: experimental studies to aid identification processes. J Forensic Odontostomatol 20(2):17-24

\section{Savio C, Merlati G, Danesino P, Fassina G, Menghini P (2006)}

Radiographic evaluation of teeth subjected to high temperatures: experimental study to aid identification processes. Forensic Sci Int 158(2):108-116

14. Reesu GV, Augustine J, Urs AB (2015) Forensic considerations when dealing with incinerated human dental remains. J Forensic Leg Med 29:13-17

15. Fereira JL, Fereira ÁED, Ortega AI (2008) Methods for the analysis of hard dental tissues exposed to high temperatures. Forensic Sci Int 178(2):119- 
16. Gouveia M (2015) Avaliação do potencial da odontometria para a diagnose sexual em vestígios humanos queimados. University of Coimbra, Dissertation

17. Morse DR (1991) Age-related changes of the dental pulp complex and their relationship to systemic aging. Oral Surg Oral Med Oral Pathol 72(6):721-745

18. Gustafson G (1950) Age determination on teeth. J Am Dent Assoc 41(1):45-54

19. Lamendin H, Baccino E, Humbert JF, Tavernier JC, Nossintchouk RM, Zerilli A (1992) A simple technique for age estimation in adult corpses: the two criteria dental method. J Forensic Sci 37(5):1373-1379

20. Yekkala R, Meers C, Van Schepdael A, Hoogmartens J, Lambrichts I, Willems $G$ (2006) Racemization of aspartic acid from human dentin in the estimation of chronological age. Forensic Sci Int 159:S89-S94

21. Cameriere R, Ferrante L, Belcastro MG, Bonfiglioli B, Rastelli E, Cingolani M (2007) Age estimation by pulp/tooth ratio in Canines by periapical x-rays. J Forensic Sci 52(1):166-170

22. Großkopf B (1989) Incremental lines in prehistoric cremated teeth. A technical note. Z Morphol Anthropol 77(3):309-311

23. Großkopf B (1990) Individualaltersbestimmung mit Hilfe von Zuwachsringen im Zement bodengelagerter menschlicher Zähne [abstract]. Z Rechtsmed 103(5):351-359

24. Czermak A, Masanz R, Brather S (2012) Age at death evaluation of urn burials (Friedenhain-Přeštovice type) from the Late Roman and Migration Period - TCA applied to cremated teeth using automated line counting (AutoTCA). 19th European Meeting of the Paleopathology Association (PPA), Lille, p 27

25. Schroeder HE, Amstad-Jossi M, Kroni R, Scherle W (1986) The periodontium. In: Schroeder HE, Amstad-Jossi M, Kroni R, Scherle W (eds) Hanbook of microscopic anatomy. Springer, Berlin, p V/5

26. Azaz B, Ulmansky M, Moshev R, Sela J (1974) Correlation between age and thickness of cementum in impacted teeth. Oral Surg Oral Med Oral 
27. Azaz B, Michaeli Y, Nitzan D (1977) Aging of tissues of the roots of nonfunctional human teeth (impacted canines). Oral Surg Oral Med Oral Pathol 43(4):572-578

28. Solheim T (1990) Dental cementum apposition as an indicator of age. Eur J Oral Sci 98(6):510-519

29. Stott GG, Sis RF, Levy BM (1982) Cemental annulation as an age criterion in forensic dentistry. J Dent Res 61(6):814-817

30. Charles DK, Condon K, Cheverud JM, Buikstra JE (1986) Cementum annulation and age determination in Homo sapiens. I. Tooth variability and observer error. Am J Phys Anthropol 71(3):311-320

31. Kagerer P, Grupe G (2001) Age-at-death diagnosis and determination of life-history parameters by incremental lines in human dental cementum as an identification aid. Forensic Sci Int 118(1):75-82

32. Wittwer-Backofen U, Gampe J, Vaupel JW (2004) Tooth cementum annulation for age estimation: results from a large known-age validation study. Am J Phys Anthropol 123(2):119-129

33. Renz H, Radlanski RJ (2006) Incremental lines in root cementum of human teeth —a reliable age marker? Homo 57(1):29-50

34. Roksandic M, Vlak D, Schillaci MA, Voicu D (2009) Technical note: applicability of tooth cementum annulation to an archaeological population. Am J Phys Anthropol 140(3):583-588

35. Kvaal SI, Solheim T, Bjerketvedt D (1996) Evaluation of preparation, staining and microscopic techniques for counting incremental lines in cementum of human teeth. Biotech Histochem 71(4):165-172

36. Naji S, Colard T, Blondiaux J, Bertrand B, d'Incau E, Bocquet-Appel JP (2014) Cementochronology, to cut or not to cut? J Paleopathol, Int, dx.doi.org/ 10.1016/j.ijpp.2014.05.003

37. Colard T, Bertrand B, Naji S, Delannoy Y, Bécart A (2015) Toward the adoption of cementochronology in forensic context. Int J Legal Med 18, doi:10.1007/s00414-015-1172-8 
38. Gupta P, Kaur H, Madhu Shankari GS, Jawanda MK, Sahi N (2014) Human age estimation from tooth cementum and dentin. J Clin Diagn Res 8(4):ZC07

39. Gauthier J, Schutkowski H (2013) Assessing the application of tooth cementum annulation relative to macroscopic aging techniques in an archeological sample. Homo 64(1):42-57

40. Haavikko K (1970) The formation and the alveolar and clinical eruption of the permanent teeth: an orthopantomographic study. Suom Hammaslaak Toim $66(3): 103$

41. Perini TA, Oliveira GLD, Ornellas JDS, Oliveira FPD (2005) Technical error of measurement in anthropometry. Rev Bras Med Esporte 11(1):81-85

42. Lipsinic FE, Paunovich E, Houston GD, Robison SF (1986) Correlation of age and incremental lines in the cementum of human teeth. J Forensic Sci 31(3):982-989

43. Shipman P, Foster G, Schoeninger M (1984) Burnt bones and teeth: an experimental study of color, morphology, crystal structure and shrinkage. J Archaeol Sci 11(4):307-325

44. Endris R, Berrsche R (1985) Color change in dental tissue as a sign of thermal damage. Z Rechtsmed 94(2):109

45. Sandholzer MA, Walmsley AD, Lumley PJ, Landini G (2013) Radiologic evaluation of heat-induced shrinkage and shape preservation of human teeth using micro-CT. J Forensic Radiol Imaging 1(3):107-111

46. Bush PJ, Bush MA (2011) The next level in victim identification: materials proper-ties as an aid in victim identification. In: Bowers C (ed) Forensic dental evidence. Elsevier Academic Press, London, pp 55-72

47. Whyte TR (2001) Distinguishing remains of human cremations from burned animal bones. J Field Archaeol 28(3-4):437-448

48. Gonçalves D, Thompson TJU, Cunha E (2011) Implications of heatinduced changes in bone on the interpretation of funerary behaviour and practice. J Archaeol Sci 38(6):1308-1313 
49. Thompson TJU (2005) Heat-induced dimensional changes in bone and their consequences for forensic anthropology. J Forensic Sci 50(5):1008-1015

50. Sandholzer MA, Sui T, Korsunsky AM, Damien Walmsley A, Lumley PJ, Landini G (2014) X-ray scattering evaluation of ultrastructural changes in human dental tissues with thermal treatment. J Forensic Sci 59(3):769-774

51. Condon K, Charles DK, Cheverud JM, Buikstra JE (1986) Cementum annulation and age determination in Homo sapiens. II Estimates and accuracy. Am J Phys Anthropol 71(3):321-330

52. Maat GJ, Gerretsen RRR, Aarents MJ (2006) Improving the visibility of tooth cementum annulations by adjustment of the cutting angle of microscopic sections. Forensic Sci Int 159(Suppl: 1):S95-S99

53. Furseth R, Johansen E (1968) A microradiographic comparison of sound and carious human dental cementum. Arch Oral Biol 13(10):1197-IN13

54. Broucker A, Colard T, Penel G, Blondiaux J, Naji S (2015) The impact of periodontal disease on cementochronology age estimation. Int. J. Paleopathol ISSN 1879-9817, http://dx.doi.org/10.1016/j.ijpp.2015.09.004

55. Dias PEM, Beaini TL, Melani RFH (2010) Age estimation from dental cementum incremental lines and periodontal disease. J Forensic

Odontostomatol 28(1):13-21

56. DeHaan JD (2008) Fire and bodies. In: Schmidt CW, Symes SA (eds)

The analysis of burned human remains. Academic, London, pp 1-13 